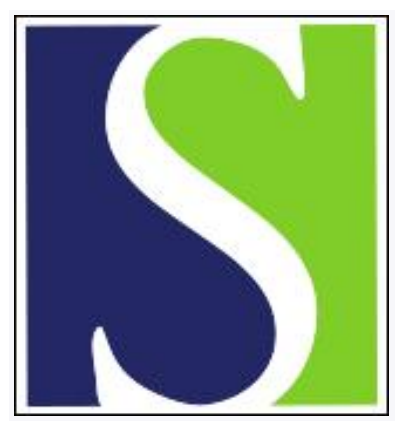

Scand J Work Environ Health 1994;20(5):322-330

https://doi.org/10.5271/sjweh.1390

Issue date: 01 Oct 1994

\title{
Bladder cancer and occupational exposures.
}

by Hours M, Dananche B, Fevotte J, Bergeret A, Ayzac L, Cardis E, Etard JF, Pallen C, Roy P, Fabry J

Affiliation: Institut d'Epidemiologie, Universite Claude Bernard, Lyon, France.

This article in PubMed: www.ncbi.nlm.nih.gov/pubmed/7863295

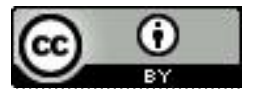




\title{
Bladder cancer and occupational exposures
}

\author{
by Martine Hours, MD, ${ }^{1}$ Brigitte Dananche, ${ }^{1}$ Joelle Fevotte, ${ }^{1}$ Alain Bergeret, MD, ${ }^{2}$ \\ Louis Ayzac, MD, ${ }^{1}$ Elisabeth Cardis, $\mathrm{PhD},{ }^{3}$ Jean François Etard, MD, ${ }^{1}$ \\ Catherine Pallen, PhD, ${ }^{1}$ Pascal Roy, MD, ${ }^{1}$ Jacques Fabry, MD ${ }^{1}$
}

\begin{abstract}
HOURS M, DANANCHE B, FEVOTTE J, BERGERET A, AYZAC L, CARDIS E, ETARD JF, PALLEN C, ROY P, FABRY J. Bladder cancer and occupational exposures. Scand $J$ Work Environ Health 1994;20:322-30.
\end{abstract}

OBJectives - A hospital-based case-referent study was carried out in Lyon with the purpose of generating hypotheses about the role of occupational exposures to 320 compounds in bladder carcinogenesis.

Methons - Job histories were obtained by questionnaire for 116 cases and 232 reference patients with diseases other than cancer (one referent from the same hospital ward and one from another ward of the same hospital per ease); the referents were matched for gender, hospital, age, and nationality. Systematic coding of exposures, with a blind analysis of job histories, was carried out by a team of experts in chemistry and occupational health.

RESULTS - Significantly elevated odds ratios were observed for exposure to pyrolysis and combustion products [odds ratio (OR) $2.3,95 \%$ confidence interval $(95 \% \mathrm{CI}) 1.0-4.0$ ] when the general referents were used and for cutting fluids (OR 2.6, 95\% CI 1.2-5.4) when tobacco consumption was adjusted for. The latter was highest among the category consisting of blue-collar and unskilled workers, supervisors, and agricultural workers (OR 4.6 95\% CI 2.0-10.6), while the odds ratio for the other category was 0.8 (95\% Cl $0.3-2.7)$. An elevated odds ratio for exposure to inks was observed for the women (OR 14.0, 95\% CI 1.8-106.5) on the basis of 14 exposed cases, but confounding factors could have been responsible for this result. Odds ratios for several other exposures (rubber: OR 5.7, nitrates: OR 8.2, coke dust: OR 3.5, meat additives: OR 3.8) were also elevated, but not significantly so when based on a small number of exposed cases.

Conclusion - The observations of this investigation should be tested in future studies, in particular since exposures to agents such as cutting fluids or pyrolysis products are ubiquitous in industrial settings and may present an important public health hazard.

KeY TERMS - case-control study, case-referent study, cutting fluids, inks, pyrolysis products.

In the history of occupational cancers, bladder tumors due to occupational exposure to aromatic amines were among the first to be recognized. Furthermore, relatively few other occupational exposures (some polycyclic aromatic hydrocarbons, eg) are recognized as being responsible for cancer of the urinary bladder (1). Several studies (2-5) have suggested that a relation exists between some occupational exposures and urothelial tumors. The relations are few, however, or the studies contradictory.

This situation is undoubtedly due to a general problem in epidemiologic studies of occupational risks for cancer. In addition to the very long latency

\footnotetext{
Institut d’Epidémiologie, Université Claude Bernard (Institute of Epidemiology, Claude Bernard University), Lyon, France.

2 Institut Universitaire de Médecine du Travail de Lyon, Université Claude Bernard (University Institute of Occupational Health, Claude Bernard University), Lyon, France.

3 International Agency for Research on Cancer, Lyon, France.
}

Reprint requests to: Dr M Hours, Institut d'Epidémiologie, Université Claude Bernard, 8 Avenue Rockefeller, 69373 Lyon Cédex 08, France. between exposure and disease (particularly in the case of urothelial tumors, for which latencies of 40 years have been observed), the multiplicity of exposures makes the identification of a particular risk factor difficult. The problem of determination of past exposures is constant in epidemiologic casereferent studies. It is of concern since misclassification reduces the power of studies and may bias the results (6).

For several years, teams of epidemiologists have sought new methods with which to evaluate exposures. One interesting solution is the use of job-exposure matrices, which allow probable exposures to be assigned systematically to a given job (7-9). The main disadvantage of these matrices is that they are only valid for a given location and for a given period, and they do not take into account the local or temporal characteristics of a job. Similarly, they assign standardized exposures to a job and do not take into account individual practices (10).

Using individual job histories analyzed by experts, Siemiatycki \& Gérin (11) have proposed a different method of evaluating chemical exposures. The exposures identified in this manner were shown to agree well with the evaluation of exposures made by specialists in relevant branches of activity (12). 
This method, adapted to the situation in France, was used in a surveillance program of occupational risks in Lyon over the last 10 years. The program used a case-referent method and dealt with three types of neoplastic diseases considered to be related to occupational exposures, malignant hemopathies (acute leukemias, malignant non-Hodgkin's lymphomas), tumors of the bladder, and bronchopulmonary cancers. This report concerns the results of the study on tumors of the urinary bladder.

\section{Subjects and methods}

\section{Data collection}

The study population consisted of 116 cases ( 97 men and 19 women) and two reference groups of 116 subjects each, matched for gender, age, hospital, and nationality. Of the cases, 28 had transitional-cell papillomas and 87 had transitional-cell carcinoma or invasive or in-situ carcinomas; one case had an undifferentiated carcinoma. The most frequent diagnoses among some of the ward referents were benign adenoma of the prostate ( 48 of 116 persons) and urinary lithiasis (22 of 116 persons). Those most common among the general referents were cardiovascular (42 of 116 persons), digestive system (18 of 116 persons), and endocrine (11 of 116 persons) diseases. The average duration of the interviews was approximately the same for each group (43 min for the cases, $42 \mathrm{~min}$ for the ward referents, $49 \mathrm{~min}$ for the general referents). The three groups did not differ with regard to their place of birth or type of residence. On the average, the cases had a higher educational level than the general referents [average age at leaving school: 15.5 (SD 3.36) years for the cases, 15.7 (SD 9.24) years for the ward referents, 14.3 (SD 3.74) years for the general referents]. Four percent of the cases refused the interview compared with $8 \%$ of the referents. In addition, several cases hospitalized less than $3 \mathrm{~d}$ could not be included since the interviewer visited the ward only twice weekly.

Table 1 gives the distribution of the cases and referents by socioprofessional category. The percentage of white-collar workers was higher among the cases than among the referents, especially among the general referents, while that of the service personnel was lower.

The enrollment of subjects for the study of urinary bladder tumors spanned four years. It included all cases diagnosed from 1984 to 1986 in the participating establishments. The collection of referents started in 1984 and was terminated in 1987. All urology wards in public hospitals were included, as well as three private hospital wards. Some specific wards were excluded from recruitment (obstetrics, emergen$c y$, intensive care, and ear, nose and throat) either due to extreme recruitment bias compared with the rest of the hospital or to conditions of hospitalization. Private clinics did not participate in the study.
It was decided to include not only primary carcinomas, but also papillomas of the urinary bladder, which are considered to be precancerous lesions. A systematic control of anatomopathological diagnoses was carried out for all cases before definite inclusion. The inclusion criterion was as follows: first hospitalization for a carcinoma or papilloma occurring among men or women aged $30-75$ years and living in the Lyon area. Two hospital referents were enrolled for each case. The first - the ward referent - was taken from the same hospital ward; the second - the general referent - was taken from another ward in the same hospital. The first patient meeting the inclusion criterion and admitted after the case was chosen as the referent. Referents were matched for gender, five-year age group, and area of residence and chosen from the patients hospitalized for diseases other than cancer or considered as occupational. French cases were matched to French referents, and foreign cases were matched to foreign referents without taking into account the country of origin.

The collection of occupational histories and data on other nonoccupational exposure variables was carried out by an interviewer during the hospitalization of the patients. The questionnaire comprised the following three parts: (i) demographic information, (ii) reconstruction of the patient's occupational history, each job being described with the aid of open questions; and (iii) closed questions inquiring into eating and smoking habits and regular leisure-time activities.

In most instances, a case and the corresponding referents were interviewed by the same person, although approximately 30 case-referent pairs were interviewed by different interviewers.

\section{Method of exposure assessment}

Coding team. A group of experts comprised of two chemical engineers and several occupational health physicians with long and varied professional experience was set up as the coding team.

Table 1. Cancer of the urinary bladder (116 cases): distribution of the 116 patients with urinary bladder cancer and their referents by socioeconomic category at the time of interview.

\begin{tabular}{|c|c|c|c|c|c|c|}
\hline \multirow{2}{*}{ Socioeconomic category } & \multicolumn{2}{|c|}{ Cases } & \multicolumn{2}{|c|}{$\begin{array}{l}\text { Ward } \\
\text { referents }\end{array}$} & \multicolumn{2}{|c|}{$\begin{array}{l}\text { General } \\
\text { referents }\end{array}$} \\
\hline & $\mathrm{N}$ & $\%$ & $N$ & $\%$ & $\mathrm{~N}$ & $\%$ \\
\hline Agricultural workers & 3 & 2.6 & 1 & 0.9 & 6 & 5.2 \\
\hline $\begin{array}{l}\text { Industrial and commercial } \\
\text { chiefs }\end{array}$ & 6 & 5.2 & 4 & 3.5 & 5 & 4.3 \\
\hline $\begin{array}{l}\text { Higher level managers } \\
\text { and professionals }\end{array}$ & 3 & 2.6 & 6 & 5.2 & 3 & 2.6 \\
\hline Intermediate level managers & 5 & 4.3 & 6 & 5.2 & 7 & 6.0 \\
\hline White-collar workers & 36 & 31.0 & 29 & 25.2 & 21 & 17.9 \\
\hline Blue-collar workers & 55 & 47.4 & 52 & 45.2 & 57 & 48.7 \\
\hline Service personnel & 5 & 4.3 & 13 & 14.4 & 17 & 15.4 \\
\hline Others and unemployed & 3 & 2.6 & 5 & 4.3 & - & 0 \\
\hline
\end{tabular}


Exposure identification. A review of possible exposures and levels of exposures in different occupational settings and time periods in the major industries of the Lyon region was carried out by the coding team. This review resulted in the creation of data bases indexed either by product (description of possible uses, evaluation of different levels of concentration) or by job, reflecting the consensus opinion of the team. These data bases were then used to code exposure history for each participant.

Choice of coding model. A list of exposures created by Michel Gérin in Canada and adapted to the local situation was used, and a total of 320 products were coded. The definition of exposures was similar to those given by Siemiatycki et al (13). Once an exposure was determined by the coder, it was assigned the following four indices to be evaluated: (i) the probable route of exposure (respiratory, dermal or mixed); (ii) the frequency of exposure (percentage of worktime during which the subject was effectively exposed) divided into the three groups of $1-5 \%$ of worktime (either approximately $30 \mathrm{~min}$ per day or two weeks per year), 5-30\% of worktime, and $\geq 30 \%$; (iii) the exposure concentration, divided into three levels (low, medium, high); and (iv) the validity, according to the coder's own judgment, of the coding (definite exposure $=3$; probable exposure $=2$; possible exposure $=1$ ).

With respect to the third index, the group of experts established its own scale of concentrations for each product. First it involved a review of all tasks with exposure to the product and then the categorization of exposure level in these tasks in comparison with the highest level of this exposure observed among all of the subjects. At the time of the coding, the concentration index thus established for an activity may have been modulated in relation to the description given by the patient (existence or $a b-$ sence of ventilation, extraction, and individual protection).

Coding protocol. Each anonymous record, without notification of diagnosis, was analyzed by an expert, who coded it and submitted his or her analysis to the group of experts. When all of the records in a study were coded, the coding was standardized to correct for the possible occurrence of the following two digressions: (i) differences in evaluation from one coder to another and (ii) changes in coding by the same coder during the course of the study.

At this stage, all of the jobs involving identical tasks were reviewed by a single chemist in order to ensure that the exposures had been coded consistently. In addition, all jobs involving exposure to a specific compound were reviewed to verify the adequacy of the assigned concentration index.

\section{Statistical analysis}

Crude odds ratios were calculated for all exposure variables coded for more than five study subjects. The confidence interval was calculated with the use of Cornfield's approximation (14) or by the exact interval calculation proposed by Mehta et al (15) when there were less than five individuals in a cell [software: Epiinfo (16)].

A conditional logistic regression analysis was used to study the effects of exposures after systematic adjustment for duration of smoking (three classes: nonsmoker, $1-27$ years, and $\geq 27$ years) and, when necessary, for the confounding effect of socioeconomic status. The specific characteristics of exposure included: duration, intensity, and age at first exposure [software: EGRET (17)].

An exposure index was defined a priori as the sum, over all exposure periods, of the product of the concentration, frequency, validity, and duration of exposure in each period. A worker was considered to have been substantially exposed to a chemical when the individual exposure index was higher than the median of this index for all of the exposed individuals (18). Other alternative indices were also studied in an attempt to evaluate the effect of concentration or that of frequency - the aforementioned index, but without the validity code - and the extent of exposure, modeled either as the product of concentration and duration or that of frequency and duration.

\section{Results}

\section{General characteristics}

Table 2 presents the crude odds ratios for the main behavioral variables; the odds ratio increased with increasing tobacco consumption, as measured in pack-years. The risk of bladder cancer appeared to be highest for the married subjects and the subjects who painted regularly in their leisure time. A deficit of bladder cancer cases was observed for consumers of artificial sweeteners when they were compared with the general referents but not when they were compared with the ward referents.

\section{Occupational exposures}

Table 3 shows crude odds ratios for several occupational exposures (coded as ever/never) with respect to both the ward and general referents. The exposures among the cases did not differ significantly from those of the ward referents, although several odds ratios were elevated (for exposure to rubber, nitrates, coke dust, and sugar dust). Exposure to pyrolysis and combustion products, cutting fluids, and inks was significantly more frequent among the cases than among the general referents. The results from the conditional logistic regression analysis (table 4), adjusting for socioprofessional status, tobacco, and 
Table 2. Crude odds ratios and $95 \%$ confidence intervals $(95 \% \mathrm{Cl})$ for different behavioral variables for the 116 cases of cancer of the urinary bladder and the ward referents and general referents.

\begin{tabular}{|c|c|c|c|c|c|c|c|}
\hline \multirow[b]{2}{*}{ Variable } & \multirow{2}{*}{$\begin{array}{c}\text { Number } \\
\text { of } \\
\text { cases }\end{array}$} & \multicolumn{3}{|c|}{ Ward referents } & \multicolumn{3}{|c|}{ General referents } \\
\hline & & $N$ & $\begin{array}{l}\text { Odds } \\
\text { ratio }\end{array}$ & $95 \% \mathrm{Cl}$ & $\mathrm{N}$ & $\begin{array}{l}\text { Odds } \\
\text { ratio }\end{array}$ & $95 \% \mathrm{Cl}$ \\
\hline \multicolumn{8}{|l|}{ Marital status } \\
\hline Married/single ${ }^{a}$ & 97 & 81 & 2.21 & $1.12-4.32$ & 86 & 2.03 & $1.03-4.03$ \\
\hline \multicolumn{8}{|l|}{ Regular leisure-time activities } \\
\hline Painting yes/no ${ }^{a}$ & 12 & 3 & 4.35 & $1.12-24.52$ & 8 & 1.56 & $0.56-4.58$ \\
\hline \multicolumn{8}{|l|}{ Diet } \\
\hline $\begin{array}{l}\text { Regular use of margarine yes } / \mathrm{no}^{\mathrm{a}} \\
\text { Regular use of sweeteners yes } / \mathrm{no}^{\mathrm{a}}\end{array}$ & $\begin{array}{l}19 \\
15\end{array}$ & $\begin{array}{l}38 \\
15\end{array}$ & $\begin{array}{l}0.40 \\
1.00\end{array}$ & $\begin{array}{l}0.20-0.79 \\
0.44-2.30\end{array}$ & $\begin{array}{l}30 \\
34\end{array}$ & $\begin{array}{l}0.56 \\
0.36\end{array}$ & $\begin{array}{l}0.28-1.12 \\
0.17-0.74\end{array}$ \\
\hline \multicolumn{8}{|l|}{ Coffee consumption } \\
\hline $\begin{array}{l}<1 \text { cup } / d^{a} \\
\leq 3 \mathrm{cups} / \mathrm{d} \\
>3 \mathrm{cups} / \mathrm{d}\end{array}$ & $\begin{array}{l}11 \\
77 \\
28\end{array}$ & $\begin{array}{l}15 \\
78 \\
23\end{array}$ & $\begin{array}{l}1 \\
1.35 \\
1.66\end{array}$ & $\begin{array}{c}0.54-3.38 \\
0.58-4.81\end{array}$ & $\begin{array}{l}12 \\
76 \\
38\end{array}$ & $\begin{array}{l}1 \\
1.38 \\
2.26\end{array}$ & $\begin{array}{c}\cdot \\
0.55-3.47 \\
1.19-4.29\end{array}$ \\
\hline \multicolumn{8}{|l|}{ Tobacco smoking } \\
\hline $\begin{array}{l}\leq 10 \text { pack-years }{ }^{a} \\
11-30 \text { pack-years } \\
>30 \text { pack-years }\end{array}$ & $\begin{array}{l}34 \\
26 \\
55\end{array}$ & $\begin{array}{l}65 \\
22 \\
29\end{array}$ & $\begin{array}{l}1 \\
2.54 \\
3.63\end{array}$ & $\begin{array}{c}\cdot \\
1.19-5.42 \\
1.88-7.02\end{array}$ & $\begin{array}{l}53 \\
24 \\
38\end{array}$ & $\begin{array}{l}1 \\
1.69 \\
2.26\end{array}$ & $\begin{array}{c}0.79-3.62 \\
1.19-4.29\end{array}$ \\
\hline \multicolumn{8}{|l|}{ Duration of smoking } \\
\hline $\begin{array}{l}0 \text { years }{ }^{a} \\
\leq 27 \text { years } \\
>27 \text { years }\end{array}$ & $\begin{array}{l}28 \\
16 \\
72\end{array}$ & $\begin{array}{l}53 \\
23 \\
40\end{array}$ & $\begin{array}{l}1 \\
1.32 \\
3.41\end{array}$ & $\begin{array}{c}\cdot \\
0.56-3.11 \\
1.79-6.50\end{array}$ & $\begin{array}{l}38 \\
26 \\
52\end{array}$ & $\begin{array}{l}1 \\
0.88 \\
1.88\end{array}$ & $\begin{array}{l}0.35-1.98 \\
0.98-3.60\end{array}$ \\
\hline
\end{tabular}

a Class used as the reference for the calculation of the odds ratio.

Table 4. Conditional logistic regression odds ratios for bladder cancer and selected exposures, as adjusted for socioprofessional status, tobacco smoking and other possible confounding exposures and with the use of both the ward referents and general referents.

\begin{tabular}{|c|c|c|c|c|c|}
\hline \multirow[b]{2}{*}{ Exposures } & \multirow{2}{*}{$\begin{array}{l}\text { Number of } \\
\text { exposed } \\
\text { cases }\end{array}$} & \multicolumn{2}{|c|}{ Ward referents } & \multicolumn{2}{|c|}{ General referents } \\
\hline & & $\begin{array}{l}\text { Crude } \\
\text { odds } \\
\text { ratio }\end{array}$ & $\begin{array}{c}95 \% \\
\text { confidence } \\
\text { interval }\end{array}$ & $\begin{array}{l}\text { Crude } \\
\text { odds } \\
\text { ratio }\end{array}$ & $\begin{array}{c}95 \% \\
\text { confidence } \\
\text { interval }\end{array}$ \\
\hline $\begin{array}{l}\text { Natural rubber } \\
\text { Pyrolysis and combustion products } \\
\text { Cutting fluids } \\
\text { Nitrates } \\
\text { Meat additives } \\
\text { Coke dust } \\
\text { Sugar dust } \\
\text { Inks }\end{array}$ & $\begin{array}{r}5 \\
44 \\
36 \\
5 \\
5 \\
7 \\
8 \\
48\end{array}$ & $\begin{array}{l}2.62 \\
1.40 \\
1.87 \\
1.94 \\
1.72 \\
2.57 \\
3.89 \\
1.88\end{array}$ & $\begin{array}{l}0.3-25.1 \\
0.8-2.6 \\
0.9-3.1 \\
0.4-9.2 \\
0.4-8.4 \\
0.6-11.4 \\
0.7-21.8 \\
1.0-3.4\end{array}$ & $\begin{array}{l}5.71 \\
2.25 \\
2.56 \\
8.20 \\
3.78 \\
3.46 \\
1.64 \\
2.01\end{array}$ & $\begin{array}{l}0.6-52.0 \\
1.0-4.0 \\
1.2-5.4 \\
0.9-77.2 \\
0.7-21.8 \\
0.7-17.9 \\
0.5-5.2 \\
1.1-3.6\end{array}$ \\
\hline
\end{tabular}

Table 3. Crude odds ratios and $95 \%$ confidence intervals for bladder cancer and selected exposures with the use of both ward referents and general referents.

\begin{tabular}{|c|c|c|c|c|c|}
\hline \multirow[b]{2}{*}{ Exposures } & \multirow{2}{*}{$\begin{array}{l}\text { Number of } \\
\text { exposed } \\
\text { cases }\end{array}$} & \multicolumn{2}{|c|}{ Ward referents } & \multicolumn{2}{|c|}{ General referents } \\
\hline & & $\begin{array}{l}\text { Crude } \\
\text { odds } \\
\text { ratio }\end{array}$ & $\begin{array}{c}95 \% \\
\text { confidence } \\
\text { interval }\end{array}$ & $\begin{array}{l}\text { Crude } \\
\text { odds } \\
\text { ratio }\end{array}$ & $\begin{array}{c}95 \% \\
\text { confidence } \\
\text { interval }\end{array}$ \\
\hline $\begin{array}{l}\text { Natural rubber } \\
\text { Pyrolysis and combustion products } \\
\text { Cutting fluids } \\
\text { Nitrates } \\
\text { Meat additives } \\
\text { Coke dust } \\
\text { Sugar dust } \\
\text { Inks }\end{array}$ & $\begin{array}{r}5 \\
44 \\
36 \\
5 \\
5 \\
7 \\
8 \\
48\end{array}$ & $\begin{array}{l}2.70 \\
1.54 \\
1.64 \\
1.75 \\
1.75 \\
2.45 \\
4.20 \\
0.96\end{array}$ & $\begin{array}{l}0.4-27.4 \\
0.9-2.8 \\
0.9-3.1 \\
0.3-11.2 \\
0.3-11.2 \\
0.5-14.8 \\
0.8-41.4 \\
0.6-1.6\end{array}$ & $\begin{array}{l}5.18 \\
2.14 \\
2.65 \\
5.18 \\
2.59 \\
3.69 \\
1.66 \\
1.88\end{array}$ & $\begin{array}{l}0.6-247.1 \\
1.2-4.0 \\
1.3-5.3 \\
0.6-247.1 \\
0.4-27.6 \\
0.7-37.0 \\
0.5-6.6 \\
1.0-3.4\end{array}$ \\
\hline
\end{tabular}


other possible confounding exposures, were consistent with these findings.

For cutting fluids, the elevated odds ratios appeared to be essentially restricted to subjects in socioprofessional group 2 (ie, blue-collar workers, service personnel, white-collar workers, and agricultural workers); they were 2.77 (95\% CI $1.24-6.19$ ) for the ward referents and 4.64 (95\% CI 2.02-10.64) for the general referents. For socioprofessional group 1 (managerial, technical, professional), the odds ratios were 0.53 (95\% CI $0.18-1.49$ ) for the ward referents and $0.83(95 \% \mathrm{Cl} 0.26-2.68)$ for the general referents. When the effect of level of exposure, as measured by the exposure index already described, was considered, the odds ratio was significantly different from 1 for subjects having received exposures below the median level when the general referents were used and for subjects with exposures above the median level when the ward referents were used (table 5). No trend with level of exposure was observed.
The results using alternative indices were similar and they have not been presented. Increased odds ratios were also seen both among the subjects with a duration of exposure of less or equal to 10 years and among those with more than 10 years of exposure when the general referents were used, although there was no trend with duration of exposure. The risk was highest among the subjects first exposed before the age of 20 years (table 5).

For pyrolysis and combustion products, the odds ratio was also significantly different from one only when the general referents were used for subjects having received exposures below the median level, as measured by the exposure index. No trend with level of exposure was observed (table 6). The results obtained with alternative indices were similar and have not been presented. Exposures to pyrolysis products and cutting fluids were extremely correlated, and it was not possible to separate the roles of these two exposures in bladder risk.

Table 5. Conditional logistic regression odds ratios and $95 \%$ confidence intervals for bladder cancer and exposure to cutting fluids, as adjusted for tobacco smoking and socioprofessional category and with the use of both ward referents and general referents.

\begin{tabular}{|c|c|c|c|c|c|}
\hline \multirow[b]{2}{*}{ Cutting fluids } & \multirow{2}{*}{$\begin{array}{l}\text { Number of } \\
\text { exposed } \\
\text { cases }\end{array}$} & \multicolumn{2}{|c|}{ Ward referents } & \multicolumn{2}{|c|}{ General referents } \\
\hline & & $\begin{array}{l}\text { Crude } \\
\text { odds } \\
\text { ratio }\end{array}$ & $\begin{array}{c}95 \% \\
\text { confidence } \\
\text { interval }^{2}\end{array}$ & $\begin{array}{l}\text { Crude } \\
\text { odds } \\
\text { ratio }\end{array}$ & $\begin{array}{c}95 \% \\
\text { confidence } \\
\text { intervala }^{\mathrm{a}}\end{array}$ \\
\hline \multicolumn{6}{|l|}{ Index ${ }^{a}$} \\
\hline $\begin{array}{l}\leq \text { Median } \\
>\text { Median }\end{array}$ & $\begin{array}{l}23 \\
13\end{array}$ & $\begin{array}{l}1.29 \\
3.21\end{array}$ & $\begin{array}{l}0.59-2.82 \\
1.03-10.02\end{array}$ & $\begin{array}{l}2.97 \\
2.08\end{array}$ & $\begin{array}{l}1.20-7.34 \\
0.75-5.77\end{array}$ \\
\hline \multicolumn{6}{|c|}{ Duration of exposure } \\
\hline $\begin{array}{l}\leq 10 \text { years } \\
>10 \text { years }\end{array}$ & $\begin{array}{l}18 \\
18\end{array}$ & $\begin{array}{l}1.37 \\
1.97\end{array}$ & $\begin{array}{l}0.57-3.30 \\
0.78-5.01\end{array}$ & $\begin{array}{l}3.11 \\
2.37\end{array}$ & $\begin{array}{l}1.15-8.40 \\
0.99-5.68\end{array}$ \\
\hline \multicolumn{6}{|c|}{ Age at beginning of exposure } \\
\hline $\begin{array}{l}\leq 20 \text { years } \\
>20 \text { years }\end{array}$ & $\begin{array}{l}21 \\
15\end{array}$ & $\begin{array}{l}1.90 \\
1.40\end{array}$ & $\begin{array}{l}0.77-4.75 \\
0.57-3.42\end{array}$ & $\begin{array}{l}4.04 \\
1.87\end{array}$ & $\begin{array}{l}1.45-11.25 \\
0.76-4.59\end{array}$ \\
\hline
\end{tabular}

a $\Sigma$ (concentration $x$ frequency $\times$ validity $\times$ duration of exposure).

Table 6. Conditional logistic regression odds ratios and $95 \%$ confidence intervals for bladder cancer and exposure to pyrolysis products, as adjusted for tobacco smoking and socioprofessional category and with the use of both ward referents and general referents.

\begin{tabular}{|c|c|c|c|c|c|}
\hline \multirow[b]{2}{*}{ Pyrolysis and combustion } & \multirow{2}{*}{$\begin{array}{l}\text { Number of } \\
\text { exposed } \\
\text { cases }\end{array}$} & \multicolumn{2}{|c|}{ Ward referents } & \multicolumn{2}{|c|}{ General referents } \\
\hline & & $\begin{array}{l}\text { Crude } \\
\text { odds } \\
\text { ratio }\end{array}$ & $\begin{array}{c}95 \% \\
\text { confidence } \\
\text { interval }{ }^{\mathrm{a}}\end{array}$ & $\begin{array}{l}\text { Crude } \\
\text { odds } \\
\text { ratio }\end{array}$ & $\begin{array}{c}95 \% \\
\text { confidence } \\
\text { interval }^{\mathrm{a}}\end{array}$ \\
\hline \multicolumn{6}{|l|}{ Index ${ }^{a}$} \\
\hline $\begin{array}{l}\leq \text { Median } \\
>\text { Median }\end{array}$ & $\begin{array}{l}18 \\
26\end{array}$ & $\begin{array}{l}2.37 \\
1.22\end{array}$ & $\begin{array}{l}0.81-6.90 \\
0.60-2.50\end{array}$ & $\begin{array}{l}2.87 \\
1.74\end{array}$ & $\begin{array}{l}1.07-7.71 \\
0.83-3.63\end{array}$ \\
\hline \multicolumn{6}{|l|}{ Duration of exposure } \\
\hline $\begin{array}{l}\leq 10 \text { years } \\
>10 \text { years }\end{array}$ & $\begin{array}{l}23 \\
21\end{array}$ & $\begin{array}{l}2.18 \\
1.12\end{array}$ & $\begin{array}{l}0.93-5.09 \\
0.53-2.38\end{array}$ & $\begin{array}{l}2.40 \\
1.80\end{array}$ & $\begin{array}{l}1.04-5.53 \\
0.82-3.91\end{array}$ \\
\hline \multicolumn{6}{|l|}{ Age at beginning of exposure } \\
\hline $\begin{array}{l}\leq 20 \text { years } \\
>20 \text { years }\end{array}$ & $\begin{array}{l}25 \\
19\end{array}$ & $\begin{array}{l}1.48 \\
1.53\end{array}$ & $\begin{array}{l}0.67-3.28 \\
0.67-3.47\end{array}$ & $\begin{array}{l}4.04 \\
1.90\end{array}$ & $\begin{array}{l}1.01-4.77 \\
0.84-4.33\end{array}$ \\
\hline
\end{tabular}

a $\Sigma$ (concentration $x$ frequency $\times$ validity $\times$ duration of exposure). 
Table 7. Conditional logistic regression odds ratios and $95 \%$ confidence intervals for bladder cancer and exposure to inks, as adjusted for tobacco smoking and socioprofessional category and with the use of both the ward referents and the general referents.

\begin{tabular}{|c|c|c|c|c|c|}
\hline \multirow[b]{2}{*}{ Inks } & \multirow{2}{*}{$\begin{array}{l}\text { Number of } \\
\text { exposed } \\
\text { cases }\end{array}$} & \multicolumn{2}{|c|}{ Ward referents } & \multicolumn{2}{|c|}{ General referents } \\
\hline & & $\begin{array}{l}\text { Crude } \\
\text { odds } \\
\text { ratio }\end{array}$ & $\begin{array}{c}95 \% \\
\text { confidence } \\
\text { interval }^{\mathrm{a}}\end{array}$ & $\begin{array}{l}\text { Crude } \\
\text { odds } \\
\text { ratio }\end{array}$ & $\begin{array}{c}95 \% \\
\text { confidence } \\
\text { intervala }^{\mathrm{a}}\end{array}$ \\
\hline \multicolumn{6}{|l|}{ Index ${ }^{a}$} \\
\hline $\begin{array}{l}\leq \text { Median } \\
>\text { Median }\end{array}$ & $\begin{array}{l}13 \\
35\end{array}$ & $\begin{array}{l}0.92 \\
1.23\end{array}$ & $\begin{array}{l}0.35-2.40 \\
0.66-2.31\end{array}$ & $\begin{array}{l}2.05 \\
1.84\end{array}$ & $\begin{array}{l}0.93-4.54 \\
0.91-3.77\end{array}$ \\
\hline \multicolumn{6}{|c|}{ Duration of exposure } \\
\hline $\begin{array}{l}\leq 10 \text { years } \\
>10 \text { years }\end{array}$ & $\begin{array}{l}23 \\
25\end{array}$ & $\begin{array}{l}0.94 \\
1.47\end{array}$ & $\begin{array}{l}0.45-1.97 \\
0.69-3.10\end{array}$ & $\begin{array}{l}1.52 \\
2.63\end{array}$ & $\begin{array}{l}0.77-3.00 \\
1.21-5.72\end{array}$ \\
\hline \multicolumn{6}{|c|}{ Age at beginning of exposure } \\
\hline $\begin{array}{l}\leq 20 \text { years } \\
>20 \text { years }\end{array}$ & $\begin{array}{l}17 \\
31\end{array}$ & $\begin{array}{l}1.81 \\
0.97\end{array}$ & $\begin{array}{l}0.69-4.73 \\
0.51-1.87\end{array}$ & $\begin{array}{l}3.06 \\
1.54\end{array}$ & $\begin{array}{l}1.15-8.12 \\
0.85-2.80\end{array}$ \\
\hline
\end{tabular}

a $\Sigma$ (concentration $x$ frequency $\times$ validity $\times$ duration of exposure).

For inks, the odds ratio increased with duration of exposure, and the risk was highest among subjects first exposed before the age of 20 years (table 7). Exposure to inks was strongly correlated with exposure to organic pigments. After adjustment for exposure to organic pigments, the corresponding odds ratio for exposure (exposed versus unexposed) to inks (both genders combined) was 3.74 (95\% CI 1.19-13.83). Elevated odds ratios appeared to be mainly restricted to women, and only one was significant, that when the general referents were used (OR 14.0, 95\% CI 1.8-106.5), with 14 exposed cases and 1 general referent. Because of the small number of exposed subjects, it was not possible to investigate this relationship further. Exposure to inks among women was mainly restricted to the category "office employees-typists."

\section{Discussion}

Numerous problems, notably recall bias and lack of knowledge of the manipulated products, always make studies of occupational exposures difficult. In order to improve the performance of case-referent studies, the team of Siemiatycki \& Gerin (Montreal) proposed a method of chemical inference (based on the study of job descriptions completed by patients) by a team of well-informed industrial hygiene analysts (18). In our study, this method of chemical inference was used after adaptation to the situation in Lyon. Several methodological aspects should be discussed.

\section{Representativeness of the subjects}

The collection of cases was not exhaustive since some stayed in the hospital only briefly $(24-48 \mathrm{~h}$ ); the characteristics - precise diagnosis, age, gender, socioprofessional class - of cases which were "missed" was examined. They did not differ from those of the cases included. This lack of exhaustiveness essentially affected the power of the study by reducing the number of cases studied. As all of the anatomopathological diagnoses were verified, misclassification of diagnosis leading to referents being classified as cases can effectively be ruled out.

A previous study in France has shown a relatively clear socioprofessional bias in the recruitment of public hospitals. This bias led to an overpresentation of blue-collar workers among the general referents, which could imply a reduction in the odds ratios thus estimated. Since three private hospital wards participated in our study, this bias was reduced. Moreover, ward referents were recruited in addition to general referents, since they tend to follow the same medical channels as the cases and, therefore, are unlikely to differ greatly with respect to socioprofessional category, although they may be closer to the cases with respect to occupational exposure. The distribution of socioprofessional categories, as anticipated, was more similar between the cases and the ward referents than between the cases and the general hospital referents (fewer white-collar workers and more single people).

Patients hospitalized for diseases other than cancer or recognized occupational disease were used as referents to prevent overmatching on exposure. As the recruitment zone of cancer cases may be larger than that of referents, only cases residing in the usual recruitment zone of the hospital (Lyon district, around 1.5 million inhabitants) were included in the study.

Interviewers received specific training prior to the start of the study. Efforts were made to ensure that cases and their matched referents were interviewed by the same person. However, due to some delay in finding some of the referents, this was not always possible. The interviewers were aware of the status of the patient at the time of the interview. This awareness did not appear to bias the results in that, for each subject, the quality of the information obtained by the interview was evaluated by the chemical exposure assessment team, the members of 
which were not aware of the status of the subject. There was no difference between the cases and referents in the quality or quantity of the information collected.

An analysis of the exposures was carried out, throughout the duration of the study, by experts or chemical engineers who had no knowledge of the status of the subject whose record they studied. A comparison of the coding of the team members showed good agreement. This approach, as discussed in the Methods section, had the important advantage of minimizing the possible misclassification of exposures and recall bias. Thus the characteristics of exposure were coded comparably for the cases and the referents.

Because of the relatively small number of cases studied $(\mathrm{N}=116)$ the power of the study was limited. Many of the odds ratios were elevated, but not significantly so. The small number of patients did not allow a detailed analysis of certain rare exposures that are known to be carcinogenic, such as aromatic amines. For the same reason, no systematic detailed analysis using all of the possible occupational confounding variables could be carried out.

On the other hand, a large number of associations were tested, and one cannot rule out the possibility that some of the significant associations may have been chance findings. There is as yet no entirely satisfactory solution to this statistical problem (18). This study was aimed, however, at surveillance and hypothesis generating, and the associations observed should be tested in future studies.

\section{Behavioral and social variables}

The cases and referents were similar with regard to behavioral or social data. However, the difference in marital status between the cases and referents was remarkable. The excess of single persons among the referents may be due to the fact that single patients may be more frequently hospitalized for nonmalignant diseases than married persons are.

The cases more frequently practiced painting as a leisure-time activity than the referents, but other types of activity were just as frequent. The fact that some carcinogenic aromatic amines have been used in paints in the past may explain this observation.

No association was found between the use of synthetic sweeteners and cancers of the urinary bladder. This finding is consistent with the majority of the results obtained over the past few years $(20)$. The excess use of sweeteners in the general reference group may have been due to the fact that five members of the group were diabetics.

Only a weak nonsignificant association was found between the consumption of coffee and cancers of the bladder. This finding may reflect a small effect of residual confounding by tobacco smoking although it is consistent with the results of many occupational studies in which a weak association be- tween coffee and cancer of the urinary bladder has been observed $(21-23)$.

A dose-related association between the risk of urinary bladder cancer and tobacco use was found which is consistent with the results of most international studies (24-27).

\section{Cancer of the bladder and occupational exposures}

Cutting fluids and combustion or pyrolysis products. The odds ratios associated with cutting fluids were elevated, in particular in the socioprofessional category most directly affected by this exposure. Higher and middle level managers, even if present in the workshops, have less direct contact with cutting fluids than workers handling metallic parts, and they therefore absorb less of the substances contained in these fluids. No dose-response or duration-related effect was observed, but this result may have been due to the relatively small number of persons studied. The odds ratio was greater for persons exposed before the age of 20 years. Other authors have found an association between exposure to cutting fluids and bladder cancer risk $(2,27)$, although it was not seen in one study (28).

Cutting fluids have been consistently associated with the risk of cancers of the skin and scrotum. This association has been attributed notably to the presence of some polycyclic aromatic hydrocarbons (PAH) in these fluids (29). PAH are suspected to be carcinogens and have been implicated in several studies linking cancers of the bladder to some occupations $(26,30-33)$. Nitrates, which are present as additives in some fluids, react to form nitrosamines $(34,35)$, which are also suspected bladder carcinogens (36). It is therefore of interest to investigate the reported association between cutting fluids and bladder cancer further in an attempt to evaluate the possible roles of PAH and nitrates.

The odds ratio for the pyrolysis and combustion of organic products was also elevated. This class of compounds regroups many exposures derived from the pyrolysis of these products, in particular PAH. Exposures to pyrolysis and combustion products and cutting fluids were strongly correlated in this study. It is therefore difficult to assess their effects independently.

Ink. An association was seen with duration of exposure and age at first exposure but not with level of exposure. This association was particularly significant for the women who had worked in typing or secretarial jobs many years ago. Exposures to inks and to organic pigments were strongly correlated. As the association was mainly restricted to women, it is conceivable that it may reflect a bias in the recruitment of the female referents. As has already been noted, middle classes tend to be underrepresented in public hospitals. This underrepresentation may partially explain the large odds ratio noted in the compari- 
son of cases to the general referents (OR 14), but not entirely since an association was also seen with the use of the ward referents. Furthermore, several publications have reported a risk for cancer of the bladder in office workers (37-39).

It would therefore be interesting to elucidate further this association in order to determine whether office inks are responsible by themselves (which appears unlikely given the low level of exposure to amines from inks) or whether the association is due to an unknown confounding factor such as, perhaps, a greater frequency of the use of hair coloring agents or the sedentary quality of the job.

In the published literature, the most frequently cited occupations that entail exposure to organic colorants and are associated with a risk for cancer of the bladder are printing (37), painting $(22,40)$, and dying $(37,39,40)$. In this study, no association between occupations for which exposure to ink was coded (printed and storekeepers) and bladder cancer risk was seen for the men.

\section{Concluding remarks}

The method used in this study to identify and quantify exposures relied on detailed analyses of occupational histories by teams of experts familiar with historical work practices in industrial settings in the Lyonnais region. This approach has allowed the study of associations between specific occupational exposures and the risk of bladder cancer to be more precise than with the standard approach using only job titles. Several plausible occupational risk factors for bladder cancer have thus been identified; some (eg, pyrolysis and combustion products and cutting fluids) have also been reported by other investigators; others (eg, exposure to inks among women) warrant further investigation.

\section{Acknowledgments}

The surveillance program on occupational cancers received support from l'Observatoire Régional de la Santé Rhône-Alpes (contracts $8 / 82$ and 30/84), The European Economic Community (contract of $21 \mathrm{De}-$ cember 1987), la Caisse Régionale d'Assurance Maladie Rhône-Alpes (contract of 1 January 1986), the Direction des relations du Travail du Ministère du Travail (conventions of 25 March 1985 and 16 November 1988), La Ligue Contre le Cancer and l'Association pour la Recherche sur Le Cancer (contract 6733).

We would like to thank the following groups of experts who participated in this study: Drs $\mathbf{J}$ Bertholon, A Chaudier, M Droin, G Duverneuil, M Ogier, A Pommier, and J Rety and Mr M Gérin and Mr R Talon, we extend our particular thanks to them, without whom this work could not have been completed; Drs F Monestier and A Robert from the Inspection Médicale du Travail and other occupational health doctors; Ms Pauguet and Ms Millet of The Service Prévention des Accidents et Maladies du Travail de la CRAM Rhône-Alpes; the heads of the urologic departments, Professors J Archimbaud, M Devonec, JM Dubernard, L Durand, and P Perrin and Drs J Cibert, P Dubernard, R Jaques and G Kepenekian; and Ms D Authier, Ms M Boeufgras, Ms C Allessandrini, Mr C Delapierre, Ms E Gachet, Ms I Gambs, Mr D Jourdan, Ms C Marti, and Mr M Sommereisen for their secretarial assistance and for interviewing the patients. We would also like to thank all of the hospital workers for facilitating our meeting of the patients.

\section{References}

1. International Agency for Research on Cancer (IARC). Polynuclear aromatic compounds: part 2, carbon blacks, mineral oils and some nitroarenes. Lyon: IARC, 1984. IARC monographs on the evaluation of the carcinogenic risks of chemicals to humans, vol 33.

2. Gonzales CA, Lopez-Abente G, Errezola M, Escolar A, Riboli E, Izarzugaza I, et al. Occupation and bladder cancer in Spain: a multi-centre case-control study. Int J Epidemiol 1989;18:569-77.

3. Silverman DT, Levin LI, Hoover RN, Hartge P. Occupational risks of bladder cancer in the United States: I white men. JNCI 1989;81(19):1472-80.

4. Steineck G, Plato N, Alfredsson L, Norell S. Industry-related urothelial carcinogens: application of a jobexposure matrix to census data. Am J Ind Med 1989;16:209-24.

5. Vineis P, Simonato L . Proportion of lung and bladder cancers in males resulting from occupation: a systematic approach. Arch Environ Health 1991;46(1):615.

6. Goldberg M. Methodes d'évaluation des expositions professionnelles: application à l'étude épidémiologique des cancers professionnels [Methods of evaluation of occupational exposures: applications to the epidemiological study of cancers of occupational origin]. Paris: Institut National de la Santé et de la Recherche Médicale/Santé Publique, 1990. Report.

7. Hoar SK, Morrison AS, Cole P, Silverman JT. An occupation and exposure linkage system for the study of occupational carcinogenesis. J Occup Med 1980;22: $722-6$.

8. Ferrario F, Continenza D, Pisani P, Magnani C, Merletti $F$, Berrino $F$. Description of a job-exposure matrix for sixteen agents which are or may be related to respiratory cancer. In: Hogstedt C, Reuterwall C, editors. Progress in occupational epidemiology. Amsterdam: Elsevier Sciences Publishers, 1988:379-82.

9. Magnani C, Coggon D, Osmond C, Acheson ED. Application of a job-exposure matrix to national mortality statistics for lung cancer. Br J Ind Med 1988;45: $70-2$.

10. Bloemhoff A, Huy TN, Van Putten DJ. The performance of a job exposure matrice compared with selfreported exposure in a case-control study of bladder cancer. In: Masson, editor. Proceedings of the 8th international symposium on epidemiology and occupational health. Paris: Masson, 1992. Revue Epidémiologie et Santé Publique, no 40.

11. Gérin M, Siemiatycki J, Kemper H, Begin D. Obtaining occupational exposure histories in epidemiologic case-control studies. J Occup Med 1985;27:420_6.

12. Siemiatycki J. An epidemiologic approach to discovering occupational exposure. Rev Adv Occup Health $1984 ; 2: 143-57$. 
13. Siemiatycki J, Nadon L, Lakhani R, Bégin D, Gérin M. Exposure assessment. Siemiatycki J, editor. Risk factors for cancer in work place. Boca Raton, FL: CRC Press, 1991:45-114.

14. Fleiss JL. Statistical methods for rates and proportions. New York, NY: John Wiley and Sons, 1981.

15. Mehta CR, Patel Nr, Gray R. Computing an exact confidence interval for the common odds ratios in several $2 * 2$ contingency tables. J Am Stat Assoc 1985;78: $969-73$

16. Dean AD, Dean JA, Burton JH, Dicker RC. Epinfo: a word processing, database and statistics program for epidemiology on microcomputers. Atlanta, GA: Centers for Disease Control, 1990.

17. EGRET A statistical package. Statistics and Epidemiology Research Corporation. 909 Northeast 43rd Street, Suite 202. Seattle Washington 98105 USA.

18. Siemiatycki J, Wacholder S, Richardson L, Dewar R, Gérin M. Discovering carcinogens in the occupational environment: methods of data collection and analysis of a large case referent monitoring system. Scand J Work Environ Health 1987;13:486 - 92 .

19. Thomas DC, Siemiatycki J, Dewar R, Robins J, Goldberg M, Armstrong BG. The problem of multiple inference in studies designed to generate hypotheses. Am J Epidemiol 1985,112:1080-95.

20. Matanovski GM, Elliott EA. Bladder cancer epidemiology. In: Nathanson N, Gordis L, editors. Epidemiologic reviews; vol 117. Baltimore, MD: John Hopkins University Press, 1981:113-127.

21. Marret LD, Walter SD, Meigs JW. Coffee drinking and bladder cancer in Connecticut. Am J Epidemiol 1983; 117:113-27.

22. Claude J, Kunze E, Frentzel-Beyme R, Paczkowski K, Schneider J, Schubert H. Life Style and occupational risk factors in cancer of the lower urinary tract. Am J Epidemiol 1986;124:578-789.

23. International Agency for Research on Cancer (IARC). Coffee, tea, mate, methylxanthines and methylglyoxal. Lyon: IARC, 1991. IARC monographs on the evaluation of the carcinogenic risks of chemicals to humans, vol 51 .

24. Vainio H, Heseltine E. Tobacco and cancer: meeting report. Cancer Res 1986;46:444-7.

25. Zaridze D, Peto R, editors. Tobacco: a major international health hazard. Lyon: International Agency for Research on Cancer (IARC), 1986. IARC scientific publications, no 74 .

26. Burns PB, Swanson GM. Risk of urinary bladder cancer among blacks and whites: the role of cigarette use and occupation. Cancer Causes Control 1991;2:3719 .

27. Cordier S, Clavel J, Limasset JC, Boccon-Gibob L, Le
Moual N, Mandereau L, Hémon D. Occupational risks of bladder cancer in France: a multicentric case-control study. Int J Epidemiol 1993;22(3):403-11.

28. Decoufle P. Further analysis of cancer mortality patterns among workers exposed to cutting oil mists. JNCI 1978;61:1025-30.

29. Thony C, Thony J, Lafontaine M. Concentration en hydrocarbures aromatiques polycycliques dans les huiles minérales [Polycyclic aromatic hydrocarbon concentration in some minérales oils]. Arch Mal Prof Hyg Toxicol Ind 1975;36:37-52.

30. Bonassi S, Merlo F, Pearce N, Puntoni R. Bladder cancer and occupational exposure to polycyclic aromatic hydrocarbons. Int J Cancer 1989;44:648 - 51.

31. Siemiatycki J, Gérin M, Stewart P, Nadon L, Dewar R, Richardson L. Associations between several sites of cancer and ten types of exhaust and combustion products: results from a case-referent study in Montreal. Scand J Work Environ Health 1988;14:79-90.

32. Smith EM, Miller ER, Woolston RF, Brown CK. Bladder cancer risk among auto and truck mechanics and chemically related occupations. Am J Public Health 1985;75:881-3.

33. Steineck G, Plato $N$, Gerhardsson $M$, Norell SE, Hogstedt C. Increased risk of urothelial cancer in Stockholm during 1985-87 after exposure to benzene and exhausts. Int J Cancer 1990;45:1012-7.

34. Fan TY, Morrison J, Rounbehler DP, Ross R, Fine DH. N-Nitrodiethanolamine in synthetic cutting fluids: a part per-hundred impurity. Science 1977;196:70-1.

35. Zingmark PA, Rappe C. On the formation of N-Nitrodiethanolamine from a grinding fluid under simulated gastric conditions. Ambio 1976;5:80-1.

36. Fraser P, Chilvers C, Beral V, Hill MJ. Nitrates and human cancer: a review of the evidence. Int $\mathrm{J}$ Epidemiol 1980;9:3-11.

37. Cartwright R. Occupational bladder cancer and cigarette smoking in West Yorkshire. Scand J Work Environ Health 1982;8 suppl 1:79-82.

38. Cole P, Hoover R, Friedell GH. Occupation and cancer of the lower urinary tract. Cancer 1972;29:125060 .

39. Risch HA, Burch JD, Miller AB, Hill GB, Steele R, Howe GR. Occupational factors and the incidence of cancer of the bladder in Canada. Br J Ind Med 1988; $45: 361-7$.

40. Jensen OM, Wahrendorf J, Knudsen JB, Sørensen BL. The Copenhagen case-referent study on bladder cancer: risks among drivers, painters, and other occupations. Scand J Work Environ Health 1987;13:129-34.

Received for publication: 14 June 1993 